\title{
ISSR Analysis of genetic diversity in Acrocarpus fraxinifolius from three landscape elements of transition forest belt of Kodagu district, Karnataka, India
}

\author{
V. Maheswarappa ${ }^{1}$, R. Vasudeva ${ }^{2}$, Ramakrishna Hegde ${ }^{3}$ and G. Ravikanth ${ }^{4}$ \\ ${ }^{1}$ College of Forestry, Ponnampet, Kodagu- 571216, Karnataka, India \\ ${ }^{2}$ Department of Forest Biology and Tree Improvement, College of Forestry, \\ Sirsi-581401, India \\ ${ }^{3}$ College of Forestry, Ponnampet-571216, India \\ ${ }^{4}$ ATREE, Bengaluru, India \\ *Corresponding author
}

\section{A B S T R A C T}

Keywords

Acrocarpus

fraxinifolius, genetic diversity, ISSR, landscapes

\section{Article Info}

Accepted:

18 August 2019 Available Online: 10 September 2019
Acrocarpus fraxinifolius is an important tropical timber species mainly found in Asia and is a fast growing tree species found naturally in India, Chaina, Burma and Sumatra. In Karnataka, the species is extensively cultivated in coffee plantations due to its desirability in the rainy season that favours coffee growth. The species is also to the smaller extent noticed in natural forests and sacred groves of Kodagu district, Karnataka, India. However there was no much studies were taken in assessing the genetic diversity of the species exists in natural forests, sacred groves and coffee plantations. Hence the study was undertaken to know the extent of genetic diversity in the species as comparing to natural forests, sacred groves and coffee plantations was analyzed using ISSR markers. The leaf samples were collected from each of landscape. DNA was extracted from leaf material using Cetyl Trimethyl Ammonium Bromide (CTAB) technique. A total of 24 ISSR markers were used for this study, but only 14 ISSR primers were successfully amplified for 8 samples. Sampled populations from all the three landscapes showed relatively higher diversity. While the sacred grove and coffee plantations populations recorded higher diversity $(0.3779$ and 0.5601: 0.3661 and 0.5403 , respectively) than natural forest population $(0.2982$ and $0.4567)$. This data clearly suggests that the farmers have conserved a higher level of diversity.

\section{Introduction}

Acrocarpus fraxinifolius Wight \& Arn possessing a botanical synonym Acrocarpus combreliflorus Teysm \& Binn emanates from the tropical regions of Asia and native of Asian tropics. Its natural and biological distribution covers India, Chaina, Burma, Borneo, Sumatra, Indonesia, Vietnam, and Bangladesh. In India is known as Mundani 
(Balangi in Karnataka), tropical Africa (Pink Cedar), in Latin America (Cedro Rosado, Mundani, Lazcar). Other vernacular names of the tree include Australian ash, Indian ash, Shingle tree (Onyango et al., 2010). Pink cedar wood act as a source for fodder, firewood for charcoal production, apiculture, timber, furniture, gum and resin. The wood is used to produce pulp for paper and has also been recommended for reinforcing river banks, stabilize terraces and used in coffee agro forestry systems (Orwa et al., 2009).

The most widely used parameter to measure diversity within populations is the expected heterozygosity or gene diversity defined by Nei (1973) as the probability that two alleles chosen at random from the population are different. Allelic diversity is an alternative criterion to measure genetic diversity and most relevant in conservation programmes as a high number of alleles imply a source of singlelocus variation for important traits (Barker, 2001).

Inter Simple Sequence Repeats (ISSR) were reported by Zietkiewicz et al., (1994) containing 100-3000 bp fragments. They are dominant markers and highly sensitive, reproducible and cost effective compared to other PCR-based markers (Reddy et al., 2002). These are either anchored at 3 ' or 5 ' end or unanchored. ISSRs do not require prior DNA sequence information and can work with small quantity (5-50 ng per reaction) template DNA detecting very low level of genetic variation effectively. ISSRs have been successfully employed in genetic diversity studies in many forest plants such as Primula obconica (Nan et al., 2003) and Gmelina arborea (Naik et al., 2009).

Lee et al., (2006) opined that to understand the variation within and among populations of plant species, understanding genetic process is very important in addition to ecological information of the species in conservation and management. The genetic diversity analysis of the species is of the first time report and hence the genetic diversity studies in Acrocarpus fraxinifolius helps in identifying the variation exists among and within the populations of natural forests, sacred groves and coffee plantations of transition forest belt of Kodagu, Karnataka, India.

\section{Materials and Methods}

\section{Description of the study site}

The study was conducted in forest-coffee agroforest landscape mosaics of Kodagu district which lies in the Central Western Ghats region, Southern India, geographically stretched between $11^{\circ} 56^{\prime}$ to $12^{\circ} 52^{\circ} \mathrm{N}$ and $75^{\circ}$ $22^{\prime}$ to $76^{\circ} 12^{\prime} \mathrm{E}$, covering an area of $4106 \mathrm{~km}^{2}$ of which about 38 per cent of area is under natural forests and tree plantations. Three landscape elements such as natural forests (NF), sacred groves (SG) and coffee plantations (CFP) were selected in transition forest belt of Kodagu, Karnataka, India.

\section{Sampling}

Leaf material was collected from adult individuals $(>10 \mathrm{~cm} \mathrm{dbh})$ in 24 accessions of Acrocarpus fraxinifolius in adjoining natural forests, sacred groves and coffee plantations. Collection of leaf material in continuous forest was restricted to plots of approximately 1 ha and to individuals at least $500 \mathrm{~m}$ apart. All the leaves were stored in individual zip lock plastic covers with labelling and shade dried in the laboratory before the DNA was extracted.

\section{DNA extraction and PCR amplifications}

DNA was extracted from leaf material (100 mg) using cetyl trimethyl ammonium bromide (CTAB) technique (Doyle and Doyle, 1987) 
and was purified using DNA easy Plant Mini kit (Qiagen,USA). The quantity and quality of the genomic DNA were assessed using Nanodrop2000 (Thermo Fisher Scientific, USA), Qubit (Thermo Fisher Scientific, USA) and agarose gel electrophoresis. Eighteen 100$200 \mathrm{bp}$ primers were tested for the process and only those primers that produced high intensity and reproducible bands were used for the remainder of the analyses.

Amplification was conducted in an eppendorf master cycler with a heated lid. Amplification was initiated for $3 \mathrm{~min}$ at $94.0^{\circ} \mathrm{C}$, a total of 35 cycles of the following: denaturation at $94^{\circ} \mathrm{C}$ for $30 \mathrm{sec}$, annealing at $45^{\circ} \mathrm{C}$ for $1 \mathrm{~min}$, and elongation at $72^{\circ} \mathrm{C}$ for $30 \mathrm{sec}$. An additional extension at $72^{\circ} \mathrm{C}$ for $7 \mathrm{~min}$ was used to ensure that all amplified products completed their elongation. Amplification products were resolved electrophoretically on a $2 \%$ agarose gel at a constant voltage of $75 \mathrm{~V}$ for $3 \mathrm{~h}$ with a 19 TAE buffer stained with ethidium-bromide.

The bands were visualized with ethidium bromide fluorescence. Samples were assigned randomly to lanes and all gels included lanes containing DNA ladders to facilitate standardization. Gels were digitally photographed and the images of multiple gels were standardized using Alpha imager, J.H. Bio software.

\section{Data scoring and analysis}

The ISSR band profiles were treated as dominant markers and each locus was considered as a bi-allelic locus with one amplifiable and one null allele. Data were scored as 1 for the presence and 0 for the absence of a DNA band for each locus across the 24 individuals in Acrocarpus fraxinifolius. Using population genetics computer programs, genetic diversity within population was analyzed.

\section{Effective number of alleles (ne)}

The effective number of alleles was calculated by using the equation as given by Kimura and Crow (1963).

$\mathrm{Ne}=(\mathrm{NK}-1) /\left(\mathrm{K}-1+\frac{\mathrm{V}}{\mathrm{K}}\right)$

Where, $\mathrm{K}$ is the mean number of loci, $\mathrm{V}$ variation in number of loci/allele, $\mathrm{N}$ Number of Loci/bands

\section{Polymorphism Information Content (PIC)}

The level of within population genetic diversity was assed using the percentage of polymorphic loci (threshold level at 95\%) of each locus was determined using the formula as described by Weir (1990)

$\mathrm{PIC}=1-\sum \mathrm{Pij}{ }^{2}$

Where, Pi is the frequency of the $i^{\text {th }}$ allele in the genotype

\section{Nei's Gene Diversity (h)}

The average expected gene diversity was calculated using the formula given by Nei (1973) as

$h i=\frac{h 1+h 2}{\text { total number of loci }}$

Where, $h 1, h 2$ represents intralocus gene diversity (i.e., $h j=\left(1-p^{2}-q^{2}\right)$

\section{Shannon's Information Index (I)}

The genetic variation was assessed by using Shannon's Information Index (Lewontin, 1972)

$\mathrm{I}=\sum$ PilogPi 
Where, pi the frequency of the allele $i^{\text {th }}$ in the population.

\section{Clustering and Principal coordinates analysis}

Unweighted Pair Group Method with Arithmetic mean dendrogram or phenogram was constructed using set of variable data using distance based method as suggested by (Sneath and Sokal, 1973) and neighbor joining (NJ) (Saitou and Nei, 1987). The clustering and principal coordinate analysis (PCoA) of 24 populations was performed using DARwin version 6 software and PCoA relates the relationship between distance matrix elements based on their first two principal coordinates.

\section{Genetic differentiation}

\section{At the one level of population}

Coefficient of gene differentiation for one level of structure for the total population (GST) was measured by using the formula as given by Nei (1973)

$\mathrm{G}_{\mathrm{ST}}=\frac{\mathrm{HT}-\mathrm{HS}}{\mathrm{HT}}$

Where, $\mathrm{G}_{\mathrm{ST}}$ is measure of the relative differentiation among subpopulation
$\mathrm{H}_{\mathrm{T}}$ is heterozygosity in the total population

$\mathrm{H}_{\mathrm{S}}$ is the average heterozygosity in subpopulation

\section{More than one level of population}

Coefficient of gene differentiation for more than one level of structure for the total population (FSR and FST) was measured by using the formulae as given by Weir and Cockerham (1984)

Partition the variation into the diversity among subpopulation within a evergreen forest belt

$\mathrm{FSR}=\frac{\mathrm{HR}-\mathrm{HS}}{\mathrm{HR}}$

Partition of the variation among bioclimatic zones for the total population

$$
\mathrm{FST}=\frac{\mathrm{HT}-\mathrm{HR}}{\mathrm{HT}}
$$

Where, $H_{R}$ is the Mean allelic frequency within each group

Fixation index (FST) is a measures or values that could help to understand the degree of population differentiation within species. It is developed as a special case of Wright's Fstatistics as the most commonly used statistics in population genetics studies.

Details of the leaf material used for genetic diversity in selected tree species

\begin{tabular}{|c|c|c|c|c|c|c|}
\hline $\begin{array}{c}\text { SI } \\
\text { No. }\end{array}$ & $\begin{array}{l}\text { Landscape } \\
\text { element }\end{array}$ & Sample code & $\begin{array}{c}\text { Name of the } \\
\text { place }\end{array}$ & Latitude (N) & Longitude (E) & $\begin{array}{l}\text { Altitude } \\
\text { (m) }\end{array}$ \\
\hline 1. & \multirow{4}{*}{$\begin{array}{l}\text { Natural forests, } \\
\text { sacred grove } \\
\text { sand coffee } \\
\text { plantations }\end{array}$} & ONT & Ontiyangadi & $12^{\circ} 11^{\prime} 55.21^{\prime \prime}$ & $75^{\circ} 48^{\prime} 3.55^{\prime \prime}$ & 906 \\
\hline 2. & & NANG & Nangala & $12^{\circ} 9^{\prime} 0.14^{\prime \prime}$ & $75^{\circ} 47^{\prime} 54.56^{\prime \prime l}$ & 899 \\
\hline 3. & & HUD & Hudikeri & $12^{\circ} 1^{\prime} 38.03^{\prime \prime \prime}$ & $75^{\circ} 52^{\prime} 42.10^{\prime \prime}$ & 833 \\
\hline 4. & & SHAN & Shantalli & $12^{\circ} 28^{\prime} 52.91^{\prime \prime}$ & $75^{\circ} 47^{\prime} 36.53^{\prime \prime}$ & 1130 \\
\hline
\end{tabular}

ISSR Primers used for PCR amplification

\begin{tabular}{|l|l|c|}
\hline \multicolumn{1}{|c|}{ ISSR Primer } & \multicolumn{1}{c|}{ Sequence } & Annealing Temperature $\left({ }^{\mathbf{O}} \mathbf{C}\right)$ \\
\hline UBC873 & $(\mathrm{GACA})_{4}$ & 50 \\
\hline ISSR3 & $\mathrm{DBDA}(\mathrm{CA})_{7}$ & 45 \\
\hline ISSR4 & $\mathrm{HVH}(\mathrm{CA})_{7}$ & 45 \\
\hline ISSR6 & $(\mathrm{CA})_{8} \mathrm{RY}$ & 55 \\
\hline
\end{tabular}




\section{Analysis of Molecular Variance}

Analysis of Molecular Variance (AMOVA) is a method to detect population differentiation utilizing molecular markers and calculated using the software GenAIEx (Peakall and Smouse, 2006).

\section{Results and Discussion}

A total of 24 ISSR markers were used for this study, but only 14 ISSR primers were successfully amplified for 8 samples (Table 1 and Fig.1). Only bands that were consistently reproduced across amplifications were considered for the analysis. Bands with the same mobility were considered as identical fragments, receiving equal values, regardless of their staining intensity (Fig.1). When multiple bands in a region were difficult to resolve, data for that region of the gel was not included in the analysis. Fourteen primers produced a total of 83 bands among the Acrocarpus fraxinifolius populations. The size of the amplified products ranged from $100 \mathrm{bp}$ to $200 \mathrm{bp}$. The number of scorable bands produced per primer ranged from 1 to 39. Of the 83 amplified fragments, 41 were polymorphic with average number of bands per primer and average polymorphic bands per primer to be 5.92 and 2.92 respectively. The total number of polymorphic bands and the percentage of polymorphism ranged from 13 to 14 and $92.86 \%$ to $100 \%$ respectively. The observed number of alleles and effective number of alleles per locus was highest and comparable among individuals sampled from sacred groves and coffee plantations (2.0000 each: 1.6511 and 1.6456, respectively), while those from the natural forests found to be lowest (1.9286 and 1.4873, respectively). The diversity computed based Nei's formulae and Shannon's information index showed consistent results. Sampled populations from all the three high. landscapes showed relatively higher diversity. While the sacred grove and coffee plantations populations recorded higher diversity $(0.3779$ and 0.5601: 0.3661 and 0.5403 , respectively) than natural forest population (0.2982 and $0.4567)$. This data clearly suggests that the farmers have conserved a higher level of diversity.

The highest percentage of polymorphic loci was found among sacred groves and coffee plantations $(100 \%)$. The level of genetic diversity based on Nei's formulae and Shannon's information index showed relatively higher in sacred groves and coffee plantations (0.3779 and 0.5601: 0.3661 and 0.5403 , respectively) than natural forests (0.2982 and 0.4567). Sezen et al., (2006) who found that the levels of Miconia affinis genetic diversity within the coffee farms and forest populations were similar and agricultural colonization is a strong spatial genetic structure. The colonization pattern and high genetic diversity of $M$. affinis also points to the role of shade coffee farms as potential foci of native forest regeneration. The results also strongly confirm with findings of Gafar et al., (2014) who assessed genetic diversity using inter-simple sequence repeat (ISSR) markers for Breonadia salicina and found higher percentage of polymorphic loci (PPL) at the population level ranging from 17.1 to $23.7 \%$, with an average of $21.3 \%$. Nei's gene diversity (h) and Shannon's information index (I) values were ( 0.086 and 0.125 respectively) lower than our findings.

The coefficient for gene differentiation for one level of structure (GST) i.e., relative differentiation among sub populations of Acrocarpus fraxinifolius was more (0.6440) where as at the two structure (FST) i.e., partition of the variation for the total population was less $(0.1722)$ and within the population in the landscape elements was 
Table.1 Genetic diversity of Acrocarpus fraxinifolius populations within different landscape elements of transition forest belt based on ISSR markers (Sample size: 8 in each landscape element).

\begin{tabular}{|c|c|c|c|c|c|c|}
\hline Population & $\begin{array}{c}\text { Number of } \\
\text { Polymorphic loci } \\
\text { (NPL) }\end{array}$ & $\begin{array}{c}\text { Percentage of } \\
\text { polymorphic loci } \\
\text { (PPL) }\end{array}$ & $\begin{array}{c}\text { Observed number } \\
\text { of alleles } \\
\text { (na) }\end{array}$ & $\begin{array}{c}\text { Effective number } \\
\text { of alleles } \\
\text { (ne) }\end{array}$ & $\begin{array}{l}\text { Nei's genetic } \\
\text { diversity } \\
\text { (h) }\end{array}$ & $\begin{array}{l}\text { Shannon's } \\
\text { Information } \\
\text { Index (I) }\end{array}$ \\
\hline Natural forest & 13 & 92.86 & $1.9286( \pm 0.2673)^{*}$ & $1.4873( \pm 0.3122)^{*}$ & $0.2982( \pm 0.1530)^{*}$ & $0.4567( \pm 0.2004)^{*}$ \\
\hline Sacred grove & 14 & 100 & $2.0000( \pm 0.0000)$ & $1.6511( \pm 0.2724)$ & $0.3779( \pm 0.1081)$ & $0.5601( \pm 0.1217)$ \\
\hline Coffee plantations & 14 & 100 & $2.0000( \pm 0.0000)$ & $1.6456( \pm 0.3180)$ & $0.3661( \pm 0.1470)$ & $0.5403(0.1777)$ \\
\hline Mean & 13.667 & 97.62 & 1.9762 & 1.5947 & 0.3474 & 0.5190 \\
\hline t-value & 41.000 & 41.017 & 83.034 & 29.692 & 13.988 & 16.380 \\
\hline p-value & 0.0005 & 0.000 & 0.0001 & 0.0011 & 0.0050 & 0.0037 \\
\hline
\end{tabular}

$\mathrm{t}$ - value is based on one sample analysis, P- values $<0.05$ is significant at $95 \%$ confident interval, *values in parentheses indicate standard deviation from mean value 
Table.2 Details of genetic diversity of selected tree species using ISSR primers

\begin{tabular}{|c|l|c|}
\hline SI No. & \multicolumn{1}{|c|}{ Parameters } & Acrocarpus fraxinifolius \\
\hline $\mathbf{1}$ & Numbers of primer used & 14 \\
\hline $\mathbf{2}$ & Amplified product range (bp) & $100-200$ \\
\hline $\mathbf{3}$ & Total number of polymorphic bands & 41 \\
\hline $\mathbf{4}$ & Total number of monomorphic bands & 42 \\
\hline $\mathbf{5}$ & Total number of bands & 83 \\
\hline $\mathbf{6}$ & Average percentage of polymorphic (\%) & 97.62 \\
\hline $\mathbf{7}$ & Average number of bands/primer & 5.92 \\
\hline $\mathbf{8}$ & Average number of polymorphic bands/primer & 2.78 \\
\hline
\end{tabular}

Table.3 Analysis of molecular variance (AMOVA) for 24 individuals sampled from natural forests, sacred groves and coffee plantations in transition forest belt using ISSR markers

\begin{tabular}{|l|c|c|c|c|c|c|c|}
\hline \multicolumn{1}{|c|}{ Source } & df & SS & MS & $\begin{array}{c}\text { Estimated } \\
\text { Variance }\end{array}$ & \% Variation & $\boldsymbol{F}_{\boldsymbol{S T}}$ & P value \\
\hline Among populations & 2 & 7.333 & 3.667 & 0.164 & 6.00 & 0.065 & 0.112 \\
\hline Within populations & 21 & 49.500 & 2.357 & 2.357 & 94.00 & 0.935 & \\
\hline Total & 23 & 56.833 & & 2.521 & 100.00 & \\
\hline
\end{tabular}

Table.4 Coefficient of gene differentiation for one level and more than one level of structure for the total population in three landscape elements of transition forest belt studied based on Nei's genetic diversity using ISSR markers.

\begin{tabular}{|l|c|c|c|c|c|c|}
\hline \multicolumn{1}{|c|}{ Tree species } & $\mathbf{h}_{\mathbf{S}}$ & $\mathbf{h}_{\mathbf{T}}$ & $\mathbf{h}_{\mathbf{S}} / \mathbf{h}_{\mathbf{T}}$ & $\mathbf{G S}_{\mathbf{T}}$ & $\mathbf{F}_{\mathbf{S T}}$ & $\mathbf{F}_{\mathbf{S R}}$ \\
\hline $\begin{array}{l}\text { Acrocarpus } \\
\text { fraxinifolius }\end{array}$ & 0.3474 & 0.9761 & 0.3559 & 0.6440 & 0.1722 & 0.6963 \\
\hline
\end{tabular}

Where $h_{\mathrm{S}}$ : Average heterozygosity in sub populations, $\mathrm{h}_{\mathrm{T}}$ : Heterozygosity in the total population, $\mathrm{G}_{\mathrm{ST}}$ : Relative differentiation among sub population, $\mathrm{F}_{\mathrm{ST}}$ : Partition of the variation for the total population and $\mathrm{F}_{\mathrm{SR}}$ : Partition of the variation into the diversity among subpopulation within a zone 


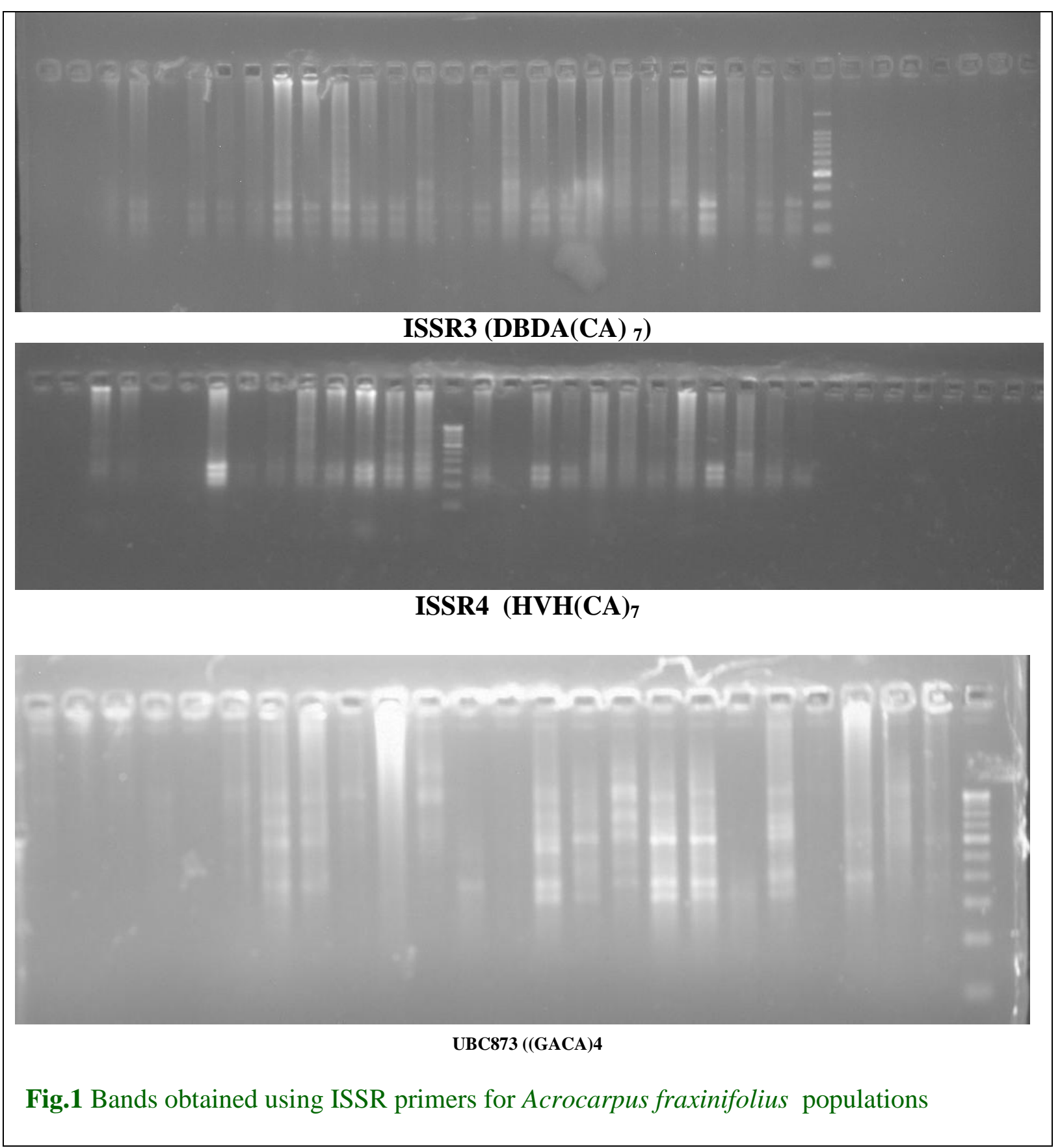


Int.J.Curr.Microbiol.App.Sci (2019) 8(9): 1611-1624

Fig.2 Hirerachial clustering of Acrocarpus fraxinifolius populations in different landscape elements of transition forest belt

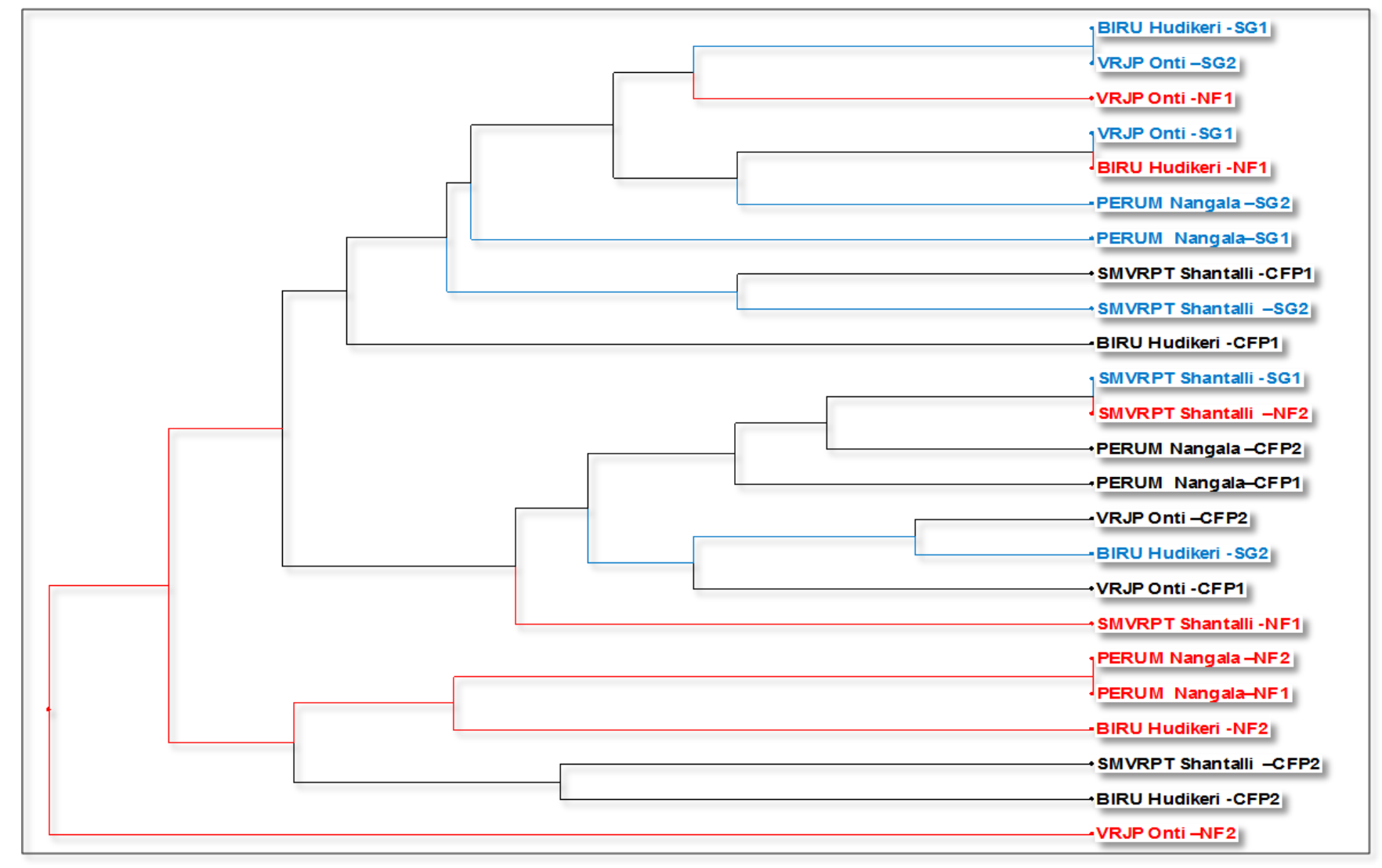

Natural forests

Sacred groves

Coffee plantations 
Int.J.Curr.Microbiol.App.Sci (2019) 8(9): 1611-1624

Fig.3 Principal co-ordinate analysis (PCoA) for Acrocarpus fraxinifolius populations in transition forest belt

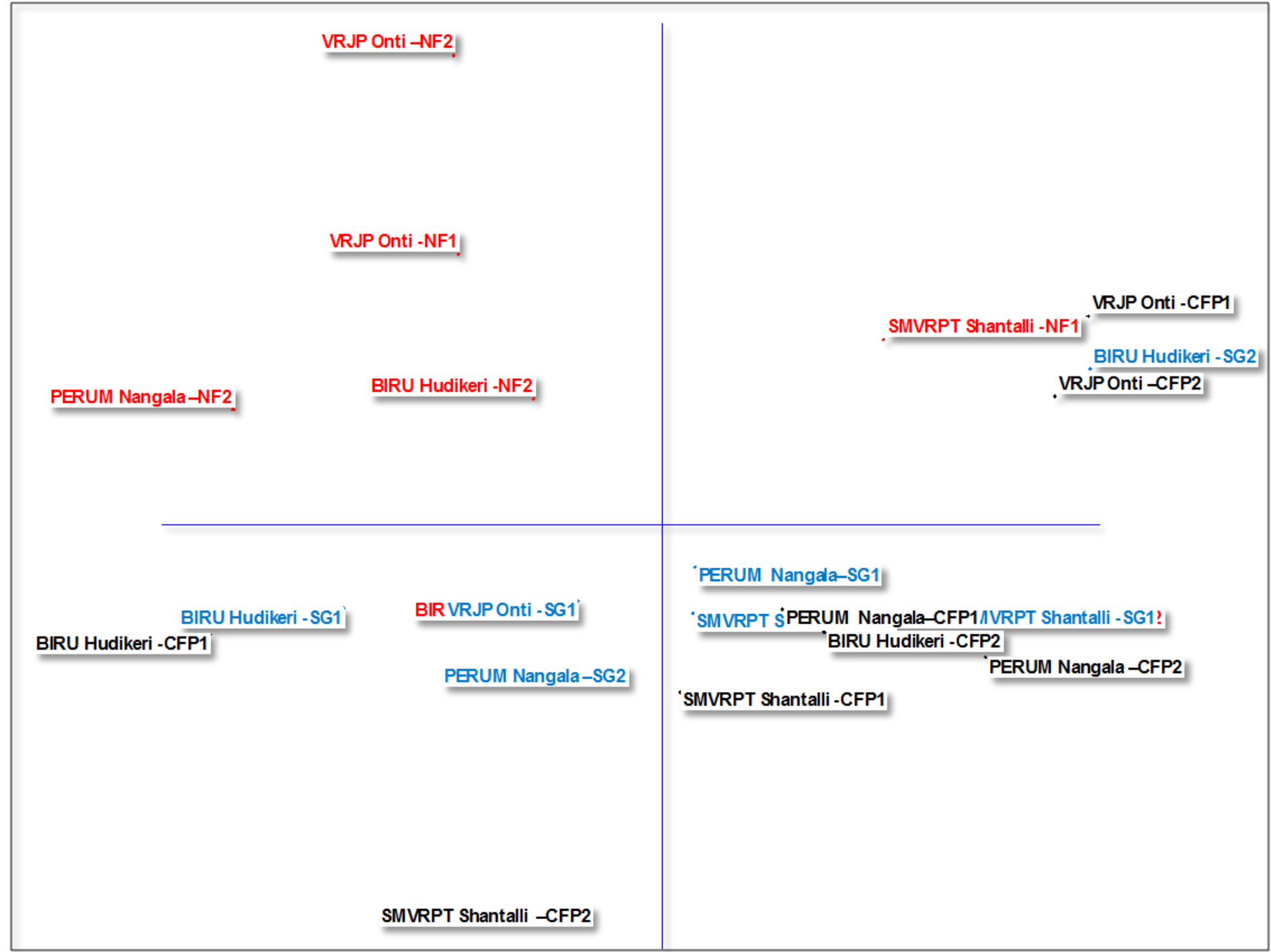


Fig.4 UPGMA phenogram based on Jaccard's dissimilarity coefficient for 24 populations of Acrocarpus fraxinifolius based on Nei's minimum genetic distance (Hierarchical joining)

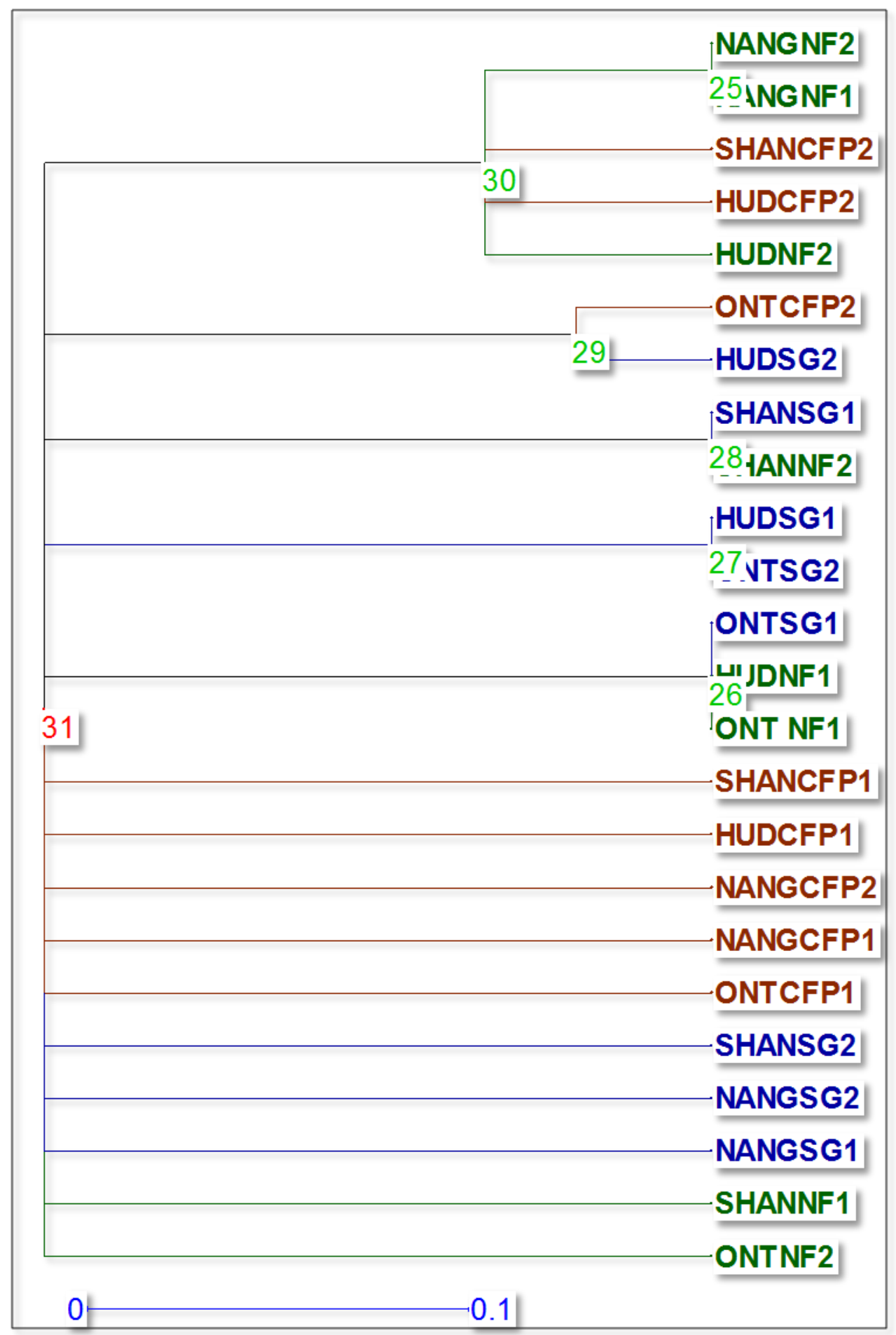


Fig.5 Neighbour joining tree for 24 populations of Acrocarpus fraxinifolius based on Nei's standard genetic distance.
Natural forests

Sacred groves

Coffee plantations

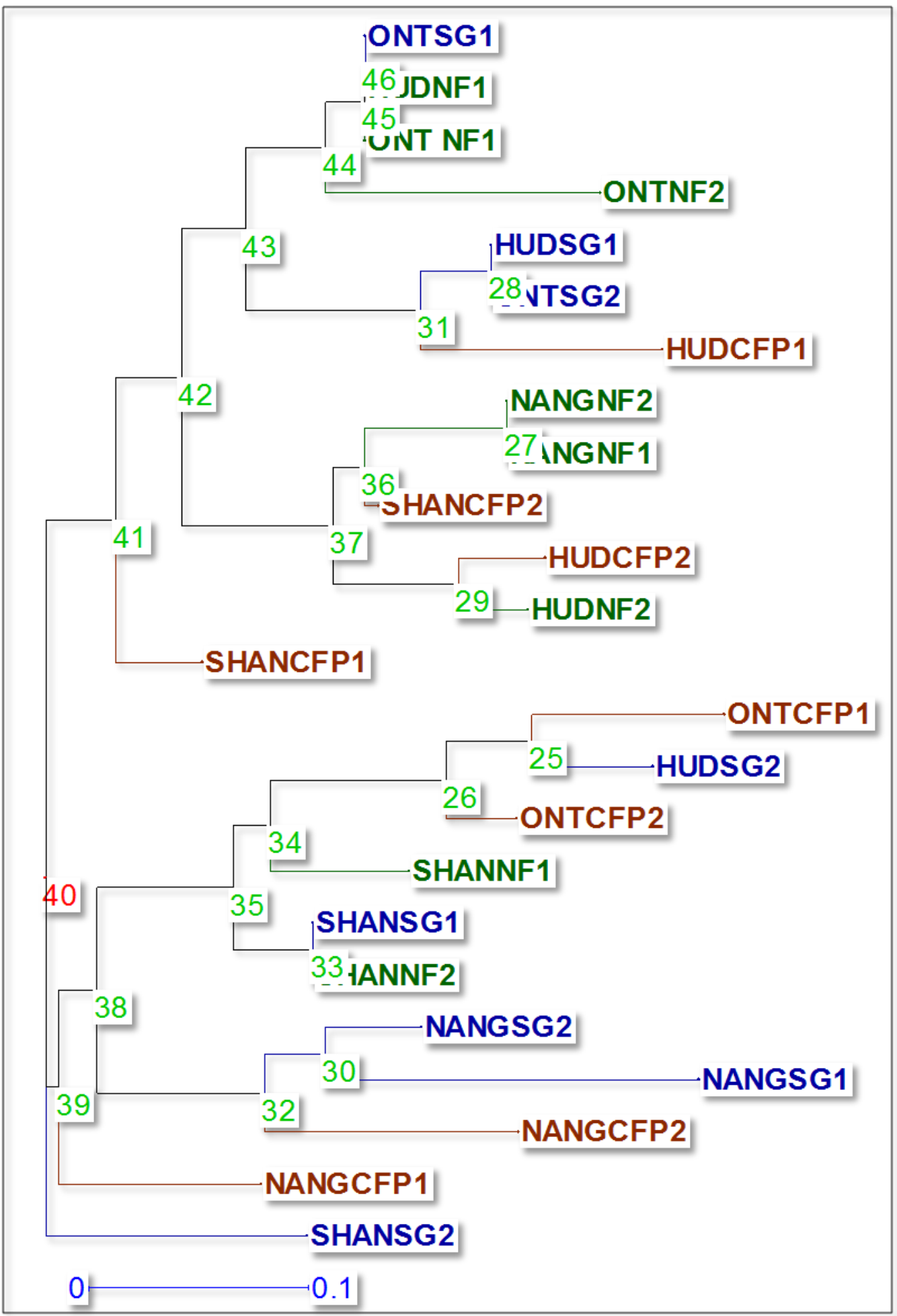


The higher and lower coefficients of gene differentiation may be due to higher wind pollination within the populations. Most of the trees were planted in coffee plantations of the zone resulted in more gene differentiation within the sub populations (Table 3 ).

Analysis of molecular variance (AMOVA) assigns a higher variation within populations $(94.00 \%)$ (Table 4). The higher variation could be attributed to outcrosses by wind and higher gene flow within the populations as described by Nybom (2004).

The populations of Acrocarpus fraxinifolius growing in natural forests of VRJP ONTI formed a separate cluster and SMVRPT, BIRU HUDKERI population growing in coffee plantation formed separate cluster. However, the species was ubiquitous over sacred groves and more linked to coffee plantation as farmers of the region intensively cultivate the species for its known use and leaf shedding character in rainy season, favouring for light penetration to coffee plantations (Fig.2 and 3).

Based on UPGMA phenogram based on Jaccard's dissimilarity coefficient for 24 populations of Acrocarpus fraxinifolius based on Nei's minimum genetic distance indicated that natural forests populations of NANG, HUD, sacred groves of HUD and coffee plantations of SHAN, HUD and ONT had lower dissimilarity and higher dissimilarity in their genetic differentiation than the others (Fig.4 and 5).

The maintenance of genetic variation is essential for long-term survival of a species since genetic diversity provides a species' evolutionary potential. In the present study ISSR marker was employed to assess the levels of genetic diversity of Acrocarpus fraxinifolius. Genetic diversity in Acrocarpus fraxinifolius populations in the three landscape elements of transitional forest belt indicated that the observed number of alleles and effective number of alleles per locus was highest and comparable among the individuals sampled from sacred groves and coffee. Sacred groves and coffee plantations population recorded higher diversity aims at planning for future conservation areas.

\section{References}

Barker, J. S. F., 2001: Conservation and management of genetic diversity: a domestic animal perspective. Canadian Journal of Forestry Research, 31: 588595.

Doyle, J.J., Doyle, J., 1987: A rapid DNA isolation procedure for small quantities of fresh leaf tissue. Phytochem. Bull. 19: 11-15.

Gafar, Z., Fahad Al-Qurainy., Salim Khan., 2014: Assessment of genetic diversity in the endangered populations of Breonadia salicina (Rubiaceae) growing in the Kingdom of Saudi Arabia using inter-simple sequence repeat markers. Genetics, 15:1-10.

Kimura, M., Crow, J. F., 1963: The measurement of effective population number. Evolution, 17: 279-288.

Lee, S. L., Ng, K. K. S., Saw, L. G., Lee, C. T., Muhammad, N., Tani, N., Tsumura, Y., Koskela, J., 2006: Linking the gaps between conservation research and conservation management of rare dipterocarps: A case study of Shorea lumutensis. Biological Conservation, 131:72-92.

Lewontin, R.C., 1972: The apportionment of human diversity. Evolutionary Biology, 6: 381-398.

Naik, D., Singh, D., Vartak, V., Paranjpe, S., Bhargava, S., 2009: Assessment of morphological and genetic diversity in Gmelina arborea Roxb. New Forest, 38 (1):99-115. 
Nan, P., Shi, S., Peng, S.L., Tian, C.J., Zhong, Y., 2003: Genetic diversity in Primula obconica (Primulaceae) from central and south-west China as revealed by ISSR markers. Annals of Botany, 91 (3):329-333.

Nei, M., 1973: Analysis of gene diversity in subdivided populations. Academia Science, 70: 3321-3323.

Nybom, H., 2004: Comparison of different nuclear DNA markers for estimating intraspecific genetic diversity in plants. Molecular Ecology, 13: 1143-1155.

Onyango, G., Ekakoro, E., Sang J., 2010: Emiti Nibwo Bulora wood lot technical specication. SCC-Vi Agroforestry.

Orwa, C.A., Mutua Kindt, R., Jamnadass, R., Anthony, S., 2009: Agroforest tree Database : a tree reference and selection guide version 4.0.

Peakall, R., Smouse, P. E., 2006: GenALEx 6: Genetic analysis in Excel. Population genetic software for teaching and research. Mol. Ecol. Notes, 6: 288-295.

Reddy, M.P., Sarla, N., Siddiq, E.A., 2002: Inter simple sequence repeat (ISSR) polymorphism and its application in plant breeding. Euphytica, 128 (1):9-
17.

Saitou, N., Nei, M., 1987: The neighborjoining method: a new method for reconstructing phylogenetic trees. Molecular Biology and Evolution, 4: 406-425.

Sezen, U.U., Chazdon, R.L., Holsinger, K.E., 2006: Genetic consequences of tropical second-growth forest regeneration. Science, 307: 891.

Sneath, P. H. A., Sokal, R. R., 1973: Numerical taxonomy. W. H. Freeman and Company, San Francisco.

Weir, B. S., 1990: Genetic data analysis Methods for discrete genetic data. Sinauer Associates Inc Sunderland.

Weir, B.S., Cockerham, C., 1984: Estimating F statistics for the analysis of population structure. Evolution, 38(6): 1358-1370.

Zietkiewicz, E., Rafalski, A., Labuda, D., 1994: Genome fingerprinting by simple sequence repeat (SSR)anchored polymerase chain reaction amplification. Genomics, 20 (2):176183.

\section{How to cite this article:}

Maheswarappa, V., R. Vasudeva, Ramakrishna Hegde and Ravikanth, G. 2019. ISSR Analysis of genetic diversity in Acrocarpus fraxinifolius from three landscape elements of transition forest belt of Kodagu district, Karnataka, India. Int.J.Curr.Microbiol.App.Sci. 8(09): 16111624. doi: https://doi.org/10.20546/ijcmas.2019.809.184 